Review

\title{
The Bioeconomy in Europe: An Overview
}

\section{Kes McCormick * and Niina Kautto}

International Institute for Industrial Environmental Economics (IIIEE), Lund University, PO Box 196, 22100 Lund, Sweden

* Author to whom correspondence should be addressed; E-Mail: kes.mccormick@iiiee.lu.se; Tel.: +46-46-222-0200.

Received: 28 April 2013; in revised form: 27 May 2013 / Accepted: 28 May 2013 /

Published: 10 June 2013

\begin{abstract}
A bioeconomy can be defined as an economy where the basic building blocks for materials, chemicals and energy are derived from renewable biological resources. This paper provides an overview of the bioeconomy in Europe, examining it from a policy framework and concept perspective. The role of bioenergy in the bioeconomy is discussed particularly through biofuels for transport and biorefineries. The study finds that the definitions of the bioeconomy are evolving and vary depending on the actor, but display similarities such as the emphasis on economic output and a broad, cross-sectoral focus. While there is great optimism about the benefits and opportunities associated with developing an advanced bioeconomy in Europe, significant risks and trade-offs are also expressed. Furthermore, the bioeconomy concept has been criticised for presenting a technical fix and pre-empting alternative visions. To advance a competitive and sustainable bioeconomy, this paper calls for attention on two important themes: participatory governance that engages the general public and key stakeholders in an open and informed dialogue as well as a commitment by government and industry to innovation that drives concerted efforts on sustainable development of the bioeconomy.
\end{abstract}

Keywords: bioeconomy; bioenergy; Europe

\section{Introduction}

Sustainable systems of production and consumption needed to respond to societal challenges — such as climate change, natural resource scarcity and environmental pollution-demand transformative 
change. An economy founded on biomass instead of fossil fuels represents a significant shift in socioeconomic, agricultural, energy and technical systems. The concept of a bioeconomy-also called the "bio-based economy" or "knowledge-based bio-economy" (or KBBE) — can be understood as an economy where the basic building blocks for materials, chemicals and energy are derived from renewable biological resources, such as plant and animal sources [1-3]. This type of economy can meet many of the requirements for sustainability from environmental, social and economic perspectives if it is designed and implemented intelligently. The recently published policy agendas for the bioeconomy by the Organisation for Economic Cooperation and Development (OECD), the European Union (EU) and the United States of America (USA) [2-4] suggest that significant advances and support can be expected in the field over the coming decades at regional, national and international scales. In this paper, the terms bioeconomy, bio-based economy and KBBE are considered interchangeable.

Potential benefits from the transition to a bio-based economy include a reduction of greenhouse gas (GHG) emissions, decrease in dependence on fossil resources, wiser management of natural resources, and improved food security $[2,5]$. Generating employment in both urban and rural settings can also be a significant positive effect of the bioeconomy [2,5]. Furthermore, the creation of new non-food markets for agriculture (such as bioenergy) in synergy with existing food markets, and in combination with alternative income sources for farmers, can give rural areas a major boost [1]. The opportunities for positive impacts flowing from an advanced bioeconomy appear to be immense. However, while the technical potential for the bioeconomy is impressive - according to Bünger [6], for instance, over 90\% of oil-based products could be replaced by bio-based alternatives - the challenge is to increase the scale of activities (e.g., in terms of biomass production) in parallel to meeting key sustainability goals [6].

This paper provides an overview of the bioeconomy, focusing on Europe, in terms of a policy framework or agenda, and as a concept for shifting towards a bio-based economy. To facilitate understanding of the existing bioeconomy and the transition to an advanced bio-based economy, it is necessary to examine more in depth the manner in which it is defined and interpreted by different actors, and key factors influencing the development of the bioeconomy (including drivers, constraints, opportunities and risks). The need for such a review is supported by the evolving definition of the bioeconomy, and several recent initiatives and strategies taken up at various jurisdictional levels within Europe and beyond (particularly the USA). This paper investigates the role of bioenergy in the bioeconomy, in particular through a discussion on biofuels and biorefineries. Briefly, the term "biofuels" is used to describe liquid (and gaseous) biofuels for transport, while "biorefineries" imply an integrated production of energy, fuels, chemicals and other products from biomass. Biofuels are currently the most visible output of the existing bioeconomy (cf. [6-8]) and the biorefinery concept aims to replace petroleum-based refineries (cf. $[9,10]$ ) - thus, biofuels and biorefineries are closely related to the current and future bioeconomy.

The methodology behind this paper is based on a review of recent literature, including both peerreviewed material and "grey" literature (such as project, conference and workshop reports). Given the increasing amount of literature published on the topic, this review is not intended to be exhaustive and concentrates on European sources. The paper is structured so that section 2 describes the background to the research by presenting the EU bioeconomy policy framework and a recent public consultation. Section 3 discusses the bioeconomy in terms of three (intersecting) viewpoints, including definitions, 
interpretations and factors enabling or constraining the transition. Reflections on the policy challenges for the bioeconomy in Europe are presented in section 4 along with some main conclusions.

\section{Background: Policy Framework for the Bioeconomy}

While the terms bioeconomy or bio-based economy appear to have been utilised already in the early 2000s - for example by Kamm and Kamm [10] — it was in the middle of the 2000s that the bioeconomy entered into policy discussions in the European sphere [11]. However, the foundations for the bioeconomy originate from earlier strategic agendas of the European Commission (EC), including the White Paper of 1993 that highlighted the need for non-physical, knowledge-based investments, and the role of biotechnology in innovation and growth [12], whereas the Lisbon Agenda in 2000 called for global leadership in the knowledge-based economy to secure competitiveness and economic growth [13]. Furthermore, in 2002, the EC stated that the life sciences and biotechnology are "probably the most promising of the frontier technologies" with a high capacity to contribute to the achievement of the Lisbon Agenda objectives ([14], p. 8). The KBBE was then effectively launched at an international conference in 2005 [15,16] and followed up by another conference in 2007, where perspectives on the European bioeconomy for the next 20 years were outlined [17]. These two events helped establish the knowledge-based bioeconomy in European policy circles.

The EC portrays the bioeconomy as a key component for smart and green growth [2]. According to the EC [2], the bioeconomy in Europe currently has a market size of over 2 trillion Euros and provides 22 million jobs across diverse sectors, including agriculture, forestry, food, chemicals, and bioenergy (cf. $[18,19]$ ). This contributes to around $9 \%$ of the total EU labour force [2]. These figures not only highlight the significance of the existing bioeconomy to the European economy and society, but also point to opportunities to better integrate activities of different sectors and expand the output of bio-based products. Europe is considered a global leader and pioneer in a number of fields of biosciences and related technologies [11,20]. However, the USA and some countries in Asia, like China, are investing heavily into the bioeconomy. One such indication is the "National Bioeconomy Blueprint" by the USA [4] published in 2012 to reinforce its activities around the bioeconomy and biobased products. With Europe considered to lag behind these countries in market deployment [20-22], the EC fears that the long-term competitiveness of Europe is at stake [11].

A recent policy initiative supporting the European bioeconomy is the Lead Market Initiative, which was active in 2007-2011 [23]. It selected bio-based products as one of its six key sectors to encourage the market uptake of new products and services. Funding mechanisms are also intended to be boosted, including Horizon 2020 that defines the EU framework for research and innovation for 2014-2020, and thus will continue from where the Seventh Framework Programme for Research and Technological Development (FP7) finishes. Building up the KBBE was the chief purpose of funding in the FP7 research theme on "Food, Agriculture and Fisheries, and Biotechnology" (FAFB) [24] and the bioeconomy is also on the Horizon 2020 agenda. It increases funding for bioeconomy research and innovation (in fact it is proposed to more than double the funds allocated to the FAFB [11,24]), and intends to harness synergies with research programmes and funds at different levels to achieve more coherent funding $[2,11]$. 
In 2011, the EC conducted a public consultation on the bioeconomy in Europe, which received over 200 submissions from organisations and individuals across most Members States of the EU [25]. At least three main findings can be drawn from the consultation. First, the majority of respondents have an optimistic outlook on the bioeconomy with more than $60 \%$ thinking that potential benefitssuch as reductions in waste, pollution and GHG emissions - can be achieved by 2020 or 2030. Second, the majority of respondents also believe that there are a number of risks associated with the bioeconomy, including potential over-exploitation of natural resources and impacts on food security. Third, there are significant concerns over barriers hindering the development of the bioeconomy in Europe (particularly in relation to competition with the USA and Asia [20,21]), including the effectiveness of the existing research and innovation actions, insufficient access to finance, and limited policy coordination [25].

A lack of public information and understanding of the bioeconomy are also considered important issues, especially regarding benefits and risks as well as ethical issues and sustainable patterns of consumption and production [25]. In this perspective, more than $70 \%$ of the respondents call for actions related to communication and dissemination of information on the bioeconomy. Other key themes to emerge in the public consultation include fostering effective governance, promoting collaboration across disciplines and sectors, investing in interdisciplinary education and training, and ensuring robust linkages between research, innovation and implementation [25]. Overall, the definition of the bioeconomy appears to be very open, and many contentious issues remain around the design and implementation of the advanced bioeconomy.

Utilising the results of the public consultation, the EC published a combined strategy and action plan document in early 2012, entitled "Innovating for Sustainable Growth: A Bioeconomy for Europe" [2]. The strategy aims to improve the knowledge-base for the bioeconomy, encourage innovation to increase natural resource productivity in a sustainable manner, and assist the development of production systems that mitigate and adapt to the impacts of climate change. Importantly, the policy document calls for a strategic, comprehensive and coherent approach to deal with the complex and inter-dependent challenges related to the bioeconomy in Europe, such as competition between different biomass uses and potential impact on food prices. The strategy attempts to establish a basis for such an approach by seeking synergies and complementarities in policies, initiatives and sectors pertaining to the bioeconomy [2]. The actions are structured under three pillars: investments in research, innovation and skills; reinforced policy interaction and stakeholder engagement; and enhancement of markets and competitiveness in bioeconomy sectors [2,11]. Twelve main actions include: increasing cross-sectoral and multi-disciplinary research and innovation; developing standards and labels for bio-based products; and establishment of a bioeconomy observatory, launched in early 2013, aimed to evaluate progress and impact of the EU bioeconomy [26].

The EU bioeconomy policy package has been relatively well received by those involved with bio-based industries, considered for instance "a very positive step" [27], and "a milestone moment for Europe and for Europeans" that "represents a giant leap forwards in securing smarter, more sustainable growth and jobs across the member states for the future" [28]. Nevertheless, it is also regarded to lack concrete measures [27] and novel funding mechanisms [29]. Moreover, it does not set either indicative or binding targets for specific bio-based product groups, which has been recommended by the advisory group connected to the Lead Market Initiative [30]. Furthermore, the public consultation in 2011 
reflected a clear demand among respondents for increased research and development actions and implementation, and the need for linkages between international, national, and regional levels [25]. It is therefore pertinent to recognise that a number of Member States in the EU have introduced bioeconomy initiatives, including France, Germany, the Netherlands, Sweden and Finland [11]. Additionally, there are an increasing number of actions and developments at local and regional scales related to the bioeconomy and bioenergy in particular. All of this combines to create a dynamic policy background for the bioeconomy in Europe.

\section{Discussion}

The EU bioeconomy policy package and public consultation represent major milestones for shaping and promoting the advanced bioeconomy in Europe. However, there is a need to examine the many challenges and issues surrounding the bioeconomy concept. This section first discusses terminology and definitions for the bioeconomy, particularly emanating from the EC, OECD, USA as well as the International Energy Agency Bioenergy (IEA Bioenergy) and the European Association for Bioindustries (EuropaBio). Second, interpretations and debates from academia are presented, particularly the criticism of the bioeconomy. And third, the relevant factors (including opportunities and risks as well as drivers and constraints) associated with a transition towards a bio-based economy are highlighted. These cross-cutting factors are evident in the discussion on terminology and definitions as well as on the interpretations and debates around the bioeconomy.

\subsection{Defining the Bioeconomy Concept and Components}

When the KBBE concept was launched, it was suggested that the bioeconomy is "one of the oldest economic sectors known to humanity" but "the life sciences and biotechnology are transforming it into one of the newest" ([15], p. 2). According to Hilgartner [31], the term "bioeconomy" in 2007 was still relatively new. In 2013, it was found that the recognisability of the bioeconomy had increased by double (based on the amount of hits in a Google search in 2007 and 2013). The use of the term "biotechnology" has also grown significantly. With a strong push in international policy agendas, the bioeconomy has become more pervasive and national efforts by Members States in the EU are also helping to make it a part of a common policy language. Before going into how the bioeconomy has been defined and interpreted by various actors, there is a need to briefly present the key terminology related to the bioeconomy.

The progress of the bioeconomy to date has been enabled by a recent increase in scientific knowledge and technical expertise to utilise biological processes for practical applications [32]. As presented earlier, the concept of the bioeconomy initially started from the life sciences and biotechnology spheres, which has then been extended to incorporate other ideas such as the biorefinery concept. Biotechnology can be understood as the science of using living things to produce goods and services. It therefore involves manipulating and modifying organisms to create new and practical applications for primary production, health and industry [3]. There are variations of biotechnologies depending on methods used and sectors involved, such as green, red and blue biotechnologies, industrial or white biotechnology and closely related grey biotechnologies, as well as modern biotechnology $[1,3,15]$. 
Industrial biotechnology or white biotechnology uses enzymes and micro-organisms to make bio-based products in a diverse range of sectors, including chemicals, food and feed, bioenergy, paper and pulp, and textiles. In turn, grey biotechnology_once under white biotechnology_encompasses technological solutions created to protect the environment, like in the case of oil spills and purifying sewage water. Green biotechnology is applied to agricultural processes for instance to develop genetically modified crops or improve plant breeding techniques by using life science knowledge. Blue biotechnology is a term that has been used to describe the marine and aquatic applications of biotechnology, while red biotechnology relates to the health sector and for instance pharmaceuticals. Finally, modern biotechnology is used to distinguish newer applications of biotechnology, such as genetic engineering and cell fusion, from more conventional methods, such as breeding or fermentation $[1,3,15,33]$.

As explained at the outset of this paper, biofuels and biorefineries are closely related priorities to the bioeconomy. The principal products of the bioeconomy are bio-based products and bioenergy, while the fundamental technology, which will be introduced to replace petroleum-based refineries, is known as biorefineries [10]. Bio-based transport fuels are commonly categorised in three groups. First generation biofuels are made from food crops, such as wheat, sugar beet and oil seeds, while second generation biofuels are based on non-food biomass, such as lignocellulosic materials, including cereal straw and maize stalks. Third generation biofuels are in turn derived from algae. Only first generation biofuels can be currently produced on a large-scale, whereas the commercialisation of second generation biofuels is expected over the coming decades. The third generation biofuels are in a research and development phase. At the moment, the main producing countries of liquid biofuels are the USA (mostly ethanol from corn and biodiesel from soy), Brazil (ethanol from sugarcane) and the EU (mainly biodiesel from rapeseed) [1,3,34].

While biorefineries are not a totally novel concept [34], it is a young field, in which research and development are still at initial stages [35]. This is reflected in the search for an appropriate definition. The IEA Bioenergy ([34], p. 2) defines the biorefinery concept as "the sustainable processing of biomass into a spectrum of marketable products (food, feed, materials and chemicals) and energy (fuels, power and heat)". This definition has been widely used to "market" biorefineries but in practical and technical terms there is substantial room for further development of the concept. In short, the biorefinery concept aims to provide significant versatility and options in the utilisation of biomass. Minimising and recycling waste streams is also an important aspect of the biorefinery concept [7]. A main goal of biorefineries is to produce both high-value low-volume (HVLV) and low-value high-volume (LVHV) products [36,37]. Current biorefineries are mostly based on a single conversion technology but if several conversion technologies are combined together, this can reduce overall costs and provide even more flexibility in product possibilities and power generation - this is known as the integrated biorefinery-representing a major goal and future foundation for the advanced bioeconomy $[36,38,39]$.

Turning to the definition of the bioeconomy concept, the OECD ([32], p. 3) suggests it can be understood as "the aggregate set of economic operations in a society that use latent value incumbent in biological products and processes to capture new growth and welfare benefits for citizens and nations". This first definition-from 2006 - essentially includes the same idea with respect to the means to achieve growth and prosperity as the OECD description from 2009 ([3], p. 22), which focuses on 
biotechnology proposing that "the bioeconomy can be thought of as a world where biotechnology contributes a significant share of economic output". The OECD [3] further states that the bioeconomy involves three elements: the use of advanced knowledge of genes and cell processes to design and develop new processes and products; the use of renewable biomass and efficient bioprocesses to stimulate sustainable production; and the integration of biotechnology knowledge and applications across a range of sectors. The OECD argues that biotechnology can offer solutions to many of the health and resource challenges facing the world, and it also proposes that the advanced bioeconomy and biotechnology will drive significant changes in the global economy over the next 30 years [32].

Shifting to a European view, the bioeconomy is defined by the EC in its policy package as "the production of renewable biological resources and the conversion of these resources and waste streams into value added products, such as food, feed, bio-based products and bioenergy" ([2], p. 3). In addition, the EC background paper for the public consultation determines that "a bio-based economy integrates the full range of natural and renewable biological resources-land and sea resources, biodiversity and biological materials (plant, animal and microbial), through to the processing and the consumption of these bio-resources. The bioeconomy encompasses the agriculture, forestry, fisheries, food and biotechnology sectors, as well as a wide range of industrial sectors, ranging from the production of energy and chemicals to building and transport" ([40], p. 9). In turn, the USA bioeconomy blueprint ([4], p. 7), which was published soon after the EC policy package in 2012, determines that "the bioeconomy is one based on the use of research and innovation in the biological sciences to create economic activity and public benefit". All these definitions leave considerable room for discussion.

The bioeconomy concept was investigated in the EC public consultation and through 35 position papers received from organisations linked (directly or indirectly) to the bioeconomy [40]. The results of the public consultation and the position papers showed that respondents generally support the EC definition (in principle at least). However, alternative definitions or a refocusing of the definition were also suggested. For example, a public goods-oriented definition of the bio-based economy was outlined as "production paradigms that rely on biological processes and, as with natural ecosystems, use natural inputs, expend minimum amounts of energy and do not produce waste as all materials discarded by one process are inputs for another process and are reused in the ecosystem" ([40], p. 9). Many respondents advocated such a public goods-oriented strategy for the bioeconomy, which focuses on a recycling community, conservation of ecosystems, and equitable sharing [40]. In fact, the position papers and consultation show strong support for a recycling economy that prioritizes the use of renewable resources; puts energy use at the end of the chain, after reuse and recycling of materials (cascading use); and creates synergies between food, materials and fuels.

EuropaBio ([1], p. 4) places the concept of a bio-based economy in firm contrast with the current fossil-based economy by stating that "the application of biotechnology for sustainable processing and production of chemicals, materials and fuels from biomass creates an opportunity to reduce significantly our dependence on coal, oil and gas". It considers industrial biotechnology a key component of the bioeconomy [1]. This involves transforming agricultural products and organic waste into other substances, in a similar way as crude oil is utilised as a feedstock for producing chemicals [1]. In a similar way, Langeveld and Sanders ([5], p. 6) highlight the technological nature and the magnitude of the change by defining the bio-based economy as involving "technological development 
that leads to a significant replacement of fossil fuels by biomass in the production of pharmaceuticals, chemicals, materials, transportation fuels, electricity and heat".

As suggested earlier, two early European conferences on the bioeconomy have laid the foundations for the concept in Europe and put biotechnology forward as a key technological pathway. In 2005, the conference called "New Perspectives on the Knowledge-Based Bio-Economy" highlighted the importance of advancements in the life sciences and biotechnology in enabling the KBBE [15]. While the term was not specified at the conference, the KBBE has been used to signify "the sustainable, eco-efficient transformation of renewable biological resources into health, food, energy and other industrial products" ([41], p. 3; see [16] on its definition in the beginning of the KBBE agenda for the FP7). Red, grey and white biotechnologies were indicated to be the strengths of Europe, whereas green biotechnology was considered as fairly weak because of the controversy around genetically modified organisms (GMOs), leading to a slowdown in research [15].

At another important conference held in 2007, called "En Route to the Knowledge-Based Bio-Economy", key stakeholders from government, industry and academia were invited to outline perspectives of the KBBE within the next 20 years. The resulting report, so called the Cologne Paper, summarised key findings from workshops on the topics of framework, food, biomaterials and bioprocesses, bioenergy, biomedicine, and new concepts and emerging technologies [17]. While no concrete definition of the bioeconomy is given, this visionary document argues that biotechnology will be an essential element of the European economy by 2030. In particular, the Cologne Paper suggests the products of white biotechnology and bioenergy will make significant contributions to industrial production in Europe by 2030 [17].

\subsection{Interpretations and Alternative Perspectives Surrounding the Bioeconomy}

Various aspects of the bioeconomy are increasingly explored by academia. In particular, science and technology scholars provide valuable views on the existing theories and foundations behind the concept, in addition to alternative visions not often under mainstream discussion. As Hilgartner [31] highlights, the promotion and institutionalisation of the bioeconomy necessitates its definition. Early definitions for the bioeconomy provided by the OECD and the EU in the middle of the 2000s are regarded to be similar in that they both emphasise the latent (i.e. existing but inactive) value in biological materials $[42,43]$. In fact, it is argued that the KBBE framework combines the Lisbon Strategy and the OECD bioeconomy agenda [44]. In common to the OECD definitions is that they both emphasise an economic perspective and cross traditional sector boundaries. In addition, these descriptions include a higher-level aim and rough means of how to get there, reflecting the OECD [32] objectives for large-scale, society-wide impacts. However, Hilgartner [31] argues that while the concept of the bioeconomy is deliberately framed in economic terms, it places risks and ethical issues on a secondary position [31].

As to the most recent EU definition in the bioeconomy strategy and action plan [2], it can be seen to be more specific compared to the OECD definitions as it mentions particular resources and products while it leaves the wider purpose open. Furthermore, the EC specifies sectors as well as fields of science and technologies related to the bioeconomy. The public consultation [40] also yielded a description that prefers naming the sectors encompassed in the development process. EuropaBio [1] 
does name the means (biotechnology) and the purpose of reducing the use of fossil fuel dependence. The 2006 EU definition [41] shares great similarities with the one of 2012, but what is noteworthy, the products in the newer, official definition [2] are "value-added". Also, the eco-efficient and sustainable nature of the transformation from resources to products has been dropped along the way.

While the USA and the OECD 2009 descriptions are highly congruent, the former differs from the EU (and the earlier OECD) definition in that it does not mention any actual products, sectors of activity, or even that the resource is based on biomass. This difference is reflected in the scope of the documents. Pollack [45] argues that the purpose of the USA blueprint is to support biology-based businesses (also encompassing pharmaceuticals and medical devices), whereas the EU strategy concentrates on sustainable industrial processes. However, Richardson [8] suggests that the EuropaBio policy agenda in the middle of the 2000s strongly reflected the USA legislation at the time, and some of its proposals have been passed into EU policy preceding the 2012 bioeconomy strategy and action plan. More specifically, inspiration for the EuropaBio proposals to the EC (that ended up part of the policy) may have originated from the USA regarding the increase in the funding of the KBBE research programme in FP7, the forming of the Lead Market Initiative to boost the demand of bio-based products, and biofuels legislation changes (including counting second generation biofuels as double in achieving the $10 \%$ EU renewable fuels target [46]) [8]. Hence, it seems that while the exact definitions can vary, there are similar mechanisms in play in the OECD, EU and USA.

Characteristic to the concept is also that it involves a massive transformation of the current production and consumption systems. Langeveld and Sanders [5] see it to be largely technological and beyond a traditional approach to economic shifts. Parry [47] argues that the biotechnologies enabling the bioeconomy have been falsely purported as unique (as they are human constructs like, for instance, electricity and aeronautics), and their markets have actually reached some level of maturity. Furthermore, Parry ([47], p. 387) claims that the focus on uniqueness of biotechnology provides a rationale for a highly specialised agenda that requires "specialist political husbandry" and that the OECD has to claim the benefits accruing from the bioeconomy being largely prospective in order to capitalise on innovation and operationalise the bioeconomy globally.

This leads to another point of critique, that is the role in which anticipatory knowledge (or future-oriented visions and imagined futures) and preference for specific development paths play a part in advancing the bioeconomy. Anticipatory knowledge acts as an important tool of prediction despite its provisional nature. Hilgartner ([31], p. 382) characterises the OECD efforts on the bioeconomy as "future-making", both anticipating and shaping the future. In fact, the KBBE can be seen as a narrative or a story that has been constructed "to explain and interpret events both to ourselves and to other people" [48]. Birch et al. ([16], p. 2) argue that the visions of the KBBE may create "the conditions for what they seek to promote", in other words, be self-fulfilling. This is because the narrative utilises these visions to justify "particular institutional and policy changes to achieve this end" ([16], p. 2). Thus, Birch et al. [16] see the European bioeconomy agenda as a dominant agenda, that is growing in importance and pre-empts alternative solutions or visions (also called an "elite master narrative" ([44], p. 2905). Furthermore, it can be argued that policy-making should include a wider range of perspectives - also critical - to enable innovation and not to restrict societal development only to one specific perspective [16]. 
Birch et al. ([44], p. 2904) describe this dominant narrative (the KBBE) as "the sustainable capital strategy to develop the (re)productive powers of living matter in the pursuit of capital accumulation". The problem with this is that private interests (e.g., better access to patents and green public procurement) enter the policy framework along with prioritisation of particular technological sectors (like through the Lead Market Initiative mentioned earlier), and a particular knowledge, that can be privatised and commoditised, is preferred. While it may stimulate innovation, the KBBE narrative puts forth a techno-knowledge fix that solves resource shortages and inefficiencies in resource use-and favours those solutions that support accumulation of "sustainable" capital through intensification of "natural" processes and biological productivity.

There are, however, alternative perspectives. According to Levidow et al. [41,49,50]—reporting findings of the EU funded project "Co-operative Research on Environmental Problems in Europe" (CREPE) - there are two contending or diverging visions; the dominant agenda based on life sciences and genetic engineering is challenged by an agro-ecological agenda. While the life sciences vision (or the dominant account of agriculture [41]) has been favoured by the KBBE agenda-entailing harnessing agriculture and biological production systems as "biomass factories" that supply raw materials for various industrial products - in the alternative account, agro-ecological food supply chains are linked, and the value is gained through the inclusion and enhancement of farmers knowledge of natural resources in agricultural methods $[41,49,50]$. Nevertheless, even if civil society has been marginalised in the policy process, the latter vision has gained ground in the KBBE agenda (namely in the FAFB programme), thanks to the push by stakeholder networks (e.g., organic agro-food organisations) and expert proposals [49,50]. The final CREPE project report ([41], p. 13) stresses that the way the EC is currently promoting the knowledge-based economy - through "eco-efficient technofixes"-may conceal and marginalise useful innovations.

The manner in which for instance bioenergy is understood in these two visions for agricultural innovation exemplifies the difference in ways the key terms like knowledge, biological resources and economy are described. In the life sciences vision, fossil fuels should be substituted by bioenergy through the efficiency increases in the conversion of biomass to energy (and other products) gained by the redesign of plants and processing methods [49,50]. In contrast, the agro-ecological vision implies the utilisation of agricultural waste to energy on-site in farms, eliminating the need for external inputs $[49,50]$. Government policy also differs in that the life sciences agenda introduces biofuels targets and subsidies to create a European market and boost exportable innovation, whereas the agro-ecological agenda promotes bioenergy development at the farm scale [41]. As to biorefineries, they are seen as vehicles of the dominant vision that connect agriculture and energy sectors with private interests; an integrated biorefinery therefore exemplifies a "techno-knowledge fix" [44].

This discussion connects to the distributed economy model that has been suggested as an alternative strategy for the bioeconomy. Based on this concept, Luoma et al. [51] argue that there is a need for the development of a global bio-based economy and distributed production models at the local level. The distributed bio-based economy model is therefore "glocal"- both global and local. This distributed model is based on the fact that biomass cannot be easily or cheaply transported long distances. Instead, a distributed bioeconomy stresses the proximity both of the sites where raw material is acquired, and where goods and energy are produced and consumed. The success of this model is not based on economies of scale, but rather on economies of numbers. In other words, it means establishing many 
interconnected local production plants that are integrated with other nearby industries to ensure that residues and wastes are fully utilised in different processes [51].

\subsection{Influencing Factors and Impacts of the Bioeconomy}

A diverse set of forces are driving forwards and constraining the bioeconomy globally and within Europe. Some of the major influencing factors include government policy, regulatory conditions, intellectual property rights, human resources, social acceptance and market structure [3]. What further complicates the bioeconomy is that the drivers and constraints involve complex interactions and feedbacks, making it highly challenging to isolate and analyse factors. However, a principal stimulant is the demand for a sustainable supply of food, fuels and raw materials [17]. A significant growth in agricultural production and yields is required over the coming decades to meet the food demands of an ever increasing population. In parallel, climate change, energy security and economic prosperity pose massive challenges. These overarching issues framing the bioeconomy are the chief reasons for an increasing interest in its development.

The OECD [3] is optimistic about the benefits of the bioeconomy and biotechnology, which it considers can help respond to many challenges facing the world, including: increase the supply and sustainability of food, feed and fibre production; improve water quality; provide renewable energy; and improve the health of people and animals. The bioeconomy is claimed by Latham and Wilson [52] to have been adopted by the EU (and the USA) based predominantly on the "promise" of biotechnology. The OECD views the opportunities and risks associated with the bioeconomy through the development of scenarios, which examine how different drivers and events could impact the bioeconomy. Based on these scenarios, it suggests that the key factors in shaping the benefits flowing from the bioeconomy will be the "quality" of governance and the economic competitiveness of biotechnology [3].

Turning attention to Europe, the EC commissioned in 2005 the "Biotechnology for Europe" (BIO4EU) study on the implications, opportunities and challenges of modern biotechnology in Europe [33]. This study has been used to argue for greater support for the emerging bioeconomy. However, Latham and Wilson [52] criticise in length the BIO4EU report for not offering much solid proof about the prospects of the bioeconomy, and that the modern biotechnology discussed in the BIO4EU is not particularly sustainable in its current configurations. Latham and Wilson [52] openly challenge the optimistic visions for the bioeconomy both in terms of the potential for an industrial revolution and to drive sustainable development by stating that "one is forced to wonder whether the KBBE is not so much a real and substantial prospect but more a fantasy future".

The magnitude of future biomass demand is a concern voiced by Smolker ([53], p. 1) who argues that "if we simply substitute plant biomass energy in place of fossil fuel energy, we are doomed". Industry is increasingly interested in replacing fossil fuels with biomass from large-scale agriculture, and the quantities of biomass required for the projected bioeconomy is considered by Smolker [53] to demand the extension of industrial monocultures and genetically modified crop varieties. In addition to cutting our energy consumption, Smolker [53] calls for the relocalisation of the production and consumption of food and biomass, resulting in a revitalisation of community-based agriculture. This model of agriculture is based on the idea of "multifunctional" systems that can provide biomass 
production, agricultural commodities, and ecological services [54]. Such alternative visions of the bioeconomy are deeply connected with understanding opportunities and risks.

GMOs form another set of issues that remain contentious in advancing the bioeconomy, particularly in Europe. In addition to NGOs expressing concerns over the bioeconomy strategies in the USA and the EU in terms of the potentially harmful impacts on land erosion, biodiversity loss and food scarcity associated with the production and utilisation of significant amounts of biomass; many NGOs are also sceptical about the benefits of new GMOs [55]. In Europe, GMOs have been a major issue related to food production that has sparked considerable action (cf. [8]). However, discussion of GMOs is limited in the EC bioeconomy strategy and action plan [2]. With the expansion of the bioeconomy, the debate on GMOs in Europe is sure to rise again.

Factors hindering and supporting bioenergy are closely connected with the general opportunities and risks for the bioeconomy as a whole. While biomass utilisation for energy often yields multiple benefits, potential negative impacts related to bioenergy production have been voiced in areas such as food security, biodiversity and water quality [56-58]. The actualization of these impacts depends largely on the design and implementation of bioenergy systems [59]. In addition, the extent of GHG emissions reduction is primarily reliant on technology and resource management practices — of both biomass feedstocks and land [57,58,60]. The impacts of bioenergy systems are complicated not only by growing international trade [61] but also by the increasing competition for biomass resources $[9,19]$. In some ways, bioenergy can be considered a test case for the bioeconomy, particularly in regards to meeting sustainability goals.

Bioenergy and biofuels for transport have been a subject under heated debate worldwide and especially in Europe (cf. [62-66]). This criticism mostly concerns first generation biofuels. The EU policy has been a significant driver for the introduction of bio-based transport fuels. As part of the climate and energy policy package in 2008 [67], the EC set targets to achieve $20 \%$ renewable energy and $10 \%$ renewable fuels (including biofuels) in the overall EU transport petrol and diesel consumption by 2020 [46]. However, Edwards et al. [68] raise serious questions about biofuels in Europe in regards to the economic costs, feedstock availability, GHG emissions, sustainability of production systems, and impacts on food supply and biodiversity. Indirect effects, such as GHG emissions associated with land use change, have also attracted increased analysis (cf. [58,69,70]). These issues will intensify as bioenergy systems continue to expand in Europe and internationally.

One of the ways to overcome the negative impacts of first generation biofuels is the introduction of more advanced biofuels, often called second and third generation biofuels. White (industrial) and green (agricultural) biotechnologies are considered necessary to harness the latent energy of cellulosic biomass (i.e., second generation) [71]. While Richardson [8] argues that such technologies have had a significant role in the KBBE narrative, he also points out the criticism towards the role that industrial biotechnology can play in reducing GHG emissions - organic farming and other agro-ecological paths may be more viable solutions (concurring with the agro-ecological vision discussed earlier). Richardson [8] also discusses that presenting farmers and rural communities as those that primarily benefit from the KBBE has been the key source of political influence among policy-makers. Nevertheless, this depends on which farmers are discussed (European of those in developing countries), and it is based, among other things, on the notion that there is a cheap and reliable source of feedstock. According to Mathews [72] innovations related to biofuels will drive the transition of the 
petro-economy towards the bioeconomy. These include using agricultural wastes as feedstocks and utilisation of mixed perennial crops preserving the soil instead of annual monocultures. Furthermore, Mathews ([72], p. 613) emphasises the huge scope of biofuels and bioenergy, and their potential to replace "petrofuels", and that the production of biofuels can lead the "resource-productivity revolution" in which the agricultural sector has a major role to play.

The findings of Edwards et al. [68] strongly support sustainability criteria for biofuels and close monitoring of sustainability performance. In 2009, the EC established binding sustainability criteria for biofuels within the Renewable Energy Directive (RED) [46]. The sustainability criteria include requirements for biofuels for transport to reduce GHG emissions at least by $35 \%$ compared to fossil fuels, rising to $50 \%$ by 2017 , and to $60 \%$ by 2018 for new production facilities, and biofuels should also not be obtained from land with high carbon stocks or high biodiversity $[46,73]$. A different approach was chosen for the use of solid biomass and biogas for electricity, heating and cooling where the EC has not yet considered a need for European-wide sustainability requirements in the RED, but only made recommendations to Member States if they individually intend to apply sustainability criteria for solid biomass and biogas [61]. Overall, the trend in Europe is towards a greater emphasis on the sustainability of bioenergy generally and biofuels for transport in particular.

Linked to sustainability, it is argued that social perceptions of bioenergy (and the bioeconomy) will significantly influence market developments [35]. However, such attitudes are not static and can change quickly. Furthermore, social perceptions are connected to political uncertainty and supportive regulation. Policy-makers will remain hesitant to introduce or maintain strong supportive policy for bioenergy, biofuels for transport or the bioeconomy as a whole if there is a lack of social acceptance, and even more so, if there is direct public and community opposition. This remains an ongoing and increasingly difficult challenge for proponents of bioenergy and the bioeconomy. Responding to public concerns over expanding biomass utilisation for energy purposes and the bioeconomy is therefore a key area for action.

\section{Reflections: Policy Challenges for the Bioeconomy}

The identification of factors influencing the development of the bioeconomy acts as the basis for setting visions and objectives as well as strategies and actions to realise the transition towards a bio-based economy. While the manner in which the bioeconomy is and will be promoted demands greater attention, it is evident that a transformation of this magnitude does not happen without concerted efforts by government and industry. Future progress of the bioeconomy is likely to require, among others, substantial changes in technological and market development, and industrial processes, eventually affecting production and consumption patterns; also shifts in market, development and trade policies will be needed [74]. From a global perspective, the OECD [32] argues that government policy will play a decisive role in shaping the bioeconomy by stimulating or blocking developments. A major challenge facing policy-makers is to design policy schemes that promote innovation and development without locking into particular systems or technologies, or locking out future opportunities. A degree of foresight is therefore of great importance in policy formulation for the bioeconomy, so that short-term decisions may be taken without jeopardising opportunities in the long-term. Furthermore, Staffas et al. [75] suggest that in order for the full potential of the bioeconomy to be achieved, a policy 
framework that considers economic, environmental, technological, social and institutional challenges is demanded.

The EC with European industry and academia stress that the advancement of the bioeconomy demands a coherent and strategic policy approach $[1,2,18]$. For the EC, innovation and research are seen as the keys to speed the transition to an economy that diminishes dependency on fossil fuels and ameliorates the sustainability of primary production and processing industries [2]. Innovation underpins the many expectations about the bioeconomy that is considered by the EC as a response to the increasing demand for a sustainable supply of food, raw materials and biofuels; the need for Europe to increase productivity and competitiveness; and improve quality of life for European citizens. In order for a coherent bioeconomy to be enabled, the EC has outlined key actions, encompassing: investing in research, innovation and skills; promoting a participatory governance structure, policy interaction and informed public dialogue; enhancing markets and economic competitiveness of the bioeconomy; and strengthening cooperation at the international, national and regional levels [2].

This study finds that there is great optimism about the benefits and opportunities associated with the growing bioeconomy and bioenergy in Europe. However, there are also significant risks and trade-offs embedded in a large-scale increase in biomass utilisation. If the bioeconomy is designed and implemented with sustainability as a guiding principle then many of the risks can be avoided and Europe can take full advantage of the benefits that can result from a sustainable and competitive bioeconomy. Clearly, there are important decisions to be made now and in the near future that will shape the development of the bioeconomy. This overview provides some insights into the bioeconomy in terms of key definitions, interpretations and factors impacting the development of the advanced bioeconomy. While there are many issues to address, this paper also highlights two cross-cutting (and inter-connected) themes for the bioeconomy that demand concerted attention-public involvement through participatory governance and sustainable development.

\subsection{Definitions and Terminology}

It is immediately apparent that the actors directly or indirectly linked to the bioeconomy understand the concept in different ways. Also, the definitions have shown to evolve in a relatively short period of time. Nevertheless, what these descriptions have in common is that they often specify the resource and products, aim and means to reach this aim; sectors or fields of action may also be mentioned. Similar qualities include the emphasis on an economic perspective and creating public welfare; realising the latent value in biological resources; and a broad, cross-sectoral focus that allows flexible interpretations and enables (possibly) far-reaching impacts. This paper has also reaffirmed that biotechnology and the biorefinery concept are essential components of the bioeconomy, and that biofuels for transport, currently the most visible output of the bioeconomy, along with a range of bio-based products, are expected to underpin the bioeconomy.

\subsection{Interpretations and Perspectives}

The increasing academic literature on the bioeconomy as a concept and policy agenda is challenging the dominant development paths and putting forth alternative visions on energy, agriculture and the role of biomass. This paper shows that the bioeconomy concept has been labelled 
by some science and technology scholars as a technical fix where economic considerations are the priority, while ethical, social — and more broadly_sustainability issues are secondary. Looking at bioenergy helps understand diverging visions for agricultural innovation and energy systems, and the ways in which essential terms such as knowledge, biological resources and economy are described and interpreted. These perspectives offer a valuable reminder of the less considered but important options to the bioeconomy that the EC and Member States should consider when designing and implementing policies and programmes.

\subsection{Factors and Impacts}

When looking at the drivers and constraints as well as positive and negative impacts of the bioeconomy, a distinction needs to be made between the current status and near-future as opposed to the long-term future based more on visions and ideas. There are diverging visions of the bioeconomy from very optimistic about an industrial revolution in the coming decades to serious concern about potential major negative impacts, especially related to agriculture and food production. Despite some studies to define the scale and attributes of the potential of the advanced bioeconomy, there remains uncertainty about what to expect. Turning to bioenergy, the debates on the sustainability of biomass for energy can be considered both a challenge and opportunity for proponents of the bioeconomy. If the development and expansion of bioenergy systems can meet sustainability goals, then this could form a foundation for building up an advanced and sustainable bioeconomy.

\subsection{Participatory Governance}

As there are so many issues, trade-offs and decisions to be made on the design and development of the bioeconomy, a commitment to participatory governance that engages the general public and key stakeholders in an open and informed dialogue appears vital. The success of the bioeconomy will likely depend on active engagement both in policy formulation and specific projects. While there is an increasing effort on research and development, the deployment of technologies is critical to making the advanced bioeconomy a reality. A more coherent, integrated and strategic policy approach is therefore required to stimulate the bioeconomy in Europe, which is combined with a strong emphasis on collaboration. Finally, as there are alternative visions of the bioeconomy, it is important to evaluate the impacts and implications of different ways to design the bio-based economy in Europe.

\subsection{Sustainable Development}

As suggested, the drivers, constraints, risks and opportunities for the bioeconomy are mixed together in complex ways, complicating efforts to direct and shape the advanced bioeconomy. In addition to supportive and integrated policy schemes based on engaging a broad range of stakeholders, it appears that a strong commitment to sustainable development will be a key ingredient for growing the bioeconomy. This paper suggests that as the development of the bioeconomy is connected with so many challenges and contentious issues, government and industry promoting and investing in innovations that drive concerted efforts on sustainability is imperative to establishing an advanced bioeconomy in the long-term that avoids the "lure" of short-term economic gains. 


\section{Acknowledgements}

The support of the Swedish Research Council for Environment, Agricultural Sciences and Spatial Planning (FORMAS) and the Swedish Knowledge Centre for Renewable Transportation Fuels (F3 Centre) are gratefully acknowledged. The authors also thank the reviewers for their valuable comments.

\section{Conflict of Interest}

The authors declare no conflict of interest.

\section{References}

1. European Association for Bioindustries (EuropaBio). Building a Bio-based Economy for Europe in 2020; European Association for Bioindustries: Brussels, Belgium, 2011.

2. European Commission (EC). Innovating for Sustainable Growth: A Bioeconomy for Europe; COM (2012) final; European Commission: Brussels, Belgium, 2012.

3. Organisation for Economic Cooperation and Development (OECD). The Bioeconomy to 2030: Designing a Policy Agenda, Main Findings; Organisation for Economic Cooperation and Development: Paris, France, 2009.

4. White House. National Bioeconomy Blueprint; White House: Washington, DC, USA, 2012.

5. Langeveld, J.W.; Sanders, J.P.M. General Introduction. In The Biobased Economy: Biofuels, Materials and Chemicals in the Post-oil Era; Langeveld, J.W., Sanders, J.P.M., Meeusen, M., Eds.; Earthscan: London, UK, 2010; pp. 3-17.

6. Bünger, M. Biofuels: Putting Pressure on Petrol. Available online: http://www.renewableenergyworld.com/rea/news/article/2010/06/biofuels-putting-pressure-on-petrol (accessed on 13 May 2013).

7. Ragauskas, A.J.; Williams, C.K.; Davison, B.H.; Britovsek, G.; Cairney, J.; Eckert, C.A.; Frederick, W.J.; Hallet, J.P.; Leak, D.J.; Liotta, C.L.; et al. The path forward for biofuels and biomaterials. Science 2006, 311, 484-489.

8. Richardson, B. From a fossil-fuel to a biobased economy: The politics of industrial biotechnology. Environ. Plan. C 2012, 30, 282-296.

9. De Jong, E.; van Ree, R.; Sanders, J.P.M.; Langeveld, J.W.A. Biorefineries: Giving Value to Sustainable Biomass Use. In The Biobased Economy: Biofuels, Materials and Chemicals in the Post-oil Era; Langeveld, J.W., Sanders, J.P.M., Meeusen, M., Eds.; Earthscan: London, UK, 2010; pp. 111-130.

10. Kamm, B.; Kamm, M. Principles of biorefineries. Appl. Microbiol. Biot. 2004, 64, 137-145.

11. European Commission (EC). Staff Working Document on Innovating for Sustainable Growth: A Bioeconomy for Europe; SWD (2012) final; European Commission: Brussels, Belgium, 2012.

12. European Commission (EC). Growth, Competitiveness, Employment: The Challenges and Ways forward into the 21st Century; White Paper, COM (93)700; European Commission: Brussels, Belgium, 1993.

13. European Commission (EC). The Lisbon European Council: An Agenda of Economic and Social Renewal for Europe; European Commission: Brussels, Belgium, 2000. 
14. European Commission (EC). Life Sciences and Biotechnology: A strategy for Europe; COM (2002)27; European Commission: Brussels, Belgium, 2002.

15. European Commission (EC). New Perspectives on the Knowledge-Based Bio-Economy; European Commission: Brussels, Belgium, 2005.

16. Birch, K.; Levidow, L.; Papaioannou, T. Self-fulfilling prophecies of the European knowledgebased bio-economy: The discursive shaping of institutional and policy frameworks in the bio-pharmaceuticals sector. J. Knowl. Econ. 2012, doi: 10.1007/s13132-012-0117-4.

17. German Presidency. En Route to the Knowledge-Based Bio-Economy; German Presidency of the Council of the European Union: Cologne, Germany, 2007.

18. Bio-Economy Technology Platforms (BECOTEPS). The European Bioeconomy in 2030: Delivering Sustainable Growth by Addressing the Grand Societal Challenges; Bio-Economy Technology Platforms: Brussels, Belgium, 2011.

19. Clever Consult. The Knowledge Based Bio-Economy in Europe: Achievements and Challenges; Clever Consult: Brussels, Belgium, 2010.

20. ENDS Europe. EU biotech research plan. Available online: http://www.endseurope.com/ (accessed on 29 January 2012).

21. ENDS Europe. Europe 'failing to cash in on biotech innovation'. Available online: http://www.endseurope.com/ (accessed on 4 April 2012).

22. EurActiv. Bio-economy poses new competitiveness challenges to Europe. Available online: http://www.euractiv.com/innovation-enterprise/bio-economy-poses-new-competitiv-news-498984 (accessed on 20 March 2013).

23. European Commission (EC). A Lead Market Initiative for Europe; COM (2007)860 final; European Commission: Brussels, Belgium, 2007.

24. European Commission (EC). Knowledge Based Bio-Economy: Food, Agriculture, Fisheries, and Biotechnology. Available online: http://cordis.europa.eu/fp7/kbbe/home_en.html (accessed on 20 March 2013).

25. European Commission (EC). Bio-based Economy for Europe: State of Play and Future Potential-Part 1; DG Research and Innovation, European Commission: Luxembourg, Belgium, 2011.

26. European Commission (EC). Commission to launch bioeconomy observatory. Available online: http://europa.eu/rapid/press-release_IP-13-113_en.htm (accessed on 13 May 2013).

27. ENDS Europe. The bioeconomy: a silver bullet for Europe? Available online: http://www.endseurope.com/ (accessed on 4 April 2012).

28. European Association for Bioindustries (EuropaBio). EU moves to grow its own bioeconomy. Available online: http://www.europabio.org/industrial/press/commission-s-strategy-launch-eumoves-grow-its-own-bioeconomy (accessed 22 on March 2013).

29. ENDS Europe. EC unveils plan to boost bio-based economy. Available online: http://www.endseurope.com/ (accessed on 4 April 2012).

30. European Commission (EC). Lead Market Initiative: Advisory Group for Bio-based Products. Available online: http://ec.europa.eu/enterprise/policies/innovation/policy/lead-market-initiative/ files/bio-based-priority-recommendations_en.pdf(accessed on 12 May 2013). 
31. Hilgartner, S. Making the bioeconomy measurable: Politics of an emerging anticipatory machinery. Biosocieties 2007, 2, 382-386.

32. Organisation for Economic Cooperation and Development (OECD). The Bioeconomy to 2030: Designing a Policy Agenda, Scoping Document; Organisation for Economic Cooperation and Development: Paris, France, 2006.

33. Zika, E.; Papatryfon, I.; Wolf, O.; Gómez-Barbero, M.; Stein, A.J.; Block, A.K. Consequences, Opportunities and Challenges of Modern Biotechnology for Europe; European Commission, Joint Research Centre: Luxembourg, Belgium, 2007.

34. De Jong, E.; Langeveld, H.; van Ree, R. Biorefinery. Available online: http://www.biorefinery.nl/ ieabioenergy-task42/biorefinery-brochure/ (accessed on 13 May 2013).

35. Peck, P.; Bennett, S.; Bissett-Amess, R.; Lenhart, J.; Mozaffarian, H. Examining understanding, acceptance, and support for the biorefinery concept among EU policy-makers. Biofuel. Bioprod. Bior. 2009, 3, 361-383.

36. Fernando, S.; Adhikari, S.; Chandrapal, C.; Murali, N. Biorefineries: Current status, challenges, and future directions. Energ. Fuel. 2006, 20, 1727-1737.

37. Taylor, G. Biofuels and the biorefinery concept. Energ. Policy 2008, 36, 4406-4409.

38. Octave, S.; Thomas, D. Biorefinery: Toward an industrial metabolism. Biochimie 2009, 91, 659-664.

39. Realff, M.J.; Abbas, C. Industrial symbiosis: Refining the biorefinery. J. Ind. Ecol. 2003, 7, 5-9.

40. European Commission (EC). Bio-based Economy for Europe: State of play and Future Potential-Part 2; DG Research and Innovation, European Commission: Luxembourg, Belgium, 2011.

41. Levidow, L. Agricultural Innovation: Sustaining What Agriculture? For What European BioEconomy? Available online: http://crepeweb.net/wp-content/uploads/2011/02/crepe_final_report.pdf (accessed on 13 May 2013).

42. Birch, K. Knowledge, place, and power: Geographies of value in the bioeconomy. New. Genet. Soc. 2012, 31, 183-201.

43. Birch, K.; Tyfield, D. Theorizing the bioeconomy: Biovalue, biocapital, bioeconomics or ... what? Sci. Tech. Hum. Val. 2013, 38, 299-327.

44. Birch, K.; Levidow, L.; Papaioannou, T. Sustainable capital? The neoliberalization of nature and knowledge in the European 'knowledge-based bio-economy'. Sustainability 2010, 2, 2898-2918.

45. Pollack, A. White House Promotes a Bioeconomy; New York Times, 26 April 2012. Available online: http://www.nytimes.com/2012/04/26/business/energy-environment/white-house-promotesa-bioeconomy.html?_r=0 (accessed on 19 March 2013).

46. European Commission (EC). Directive 2009/28/EC on the Promotion of the Use of Energy from Renewable Sources and Amending and Subsequently Repealing Directives 2001/77/EC and 2003/30/EC; European Commission: Brussels, Belgium, 2009.

47. Parry, B. Cornering the futures market in 'bio-epistemology'. Biosocieties 2007, 2, 386-389.

48. Sikes, P.; Gale, K. Narrative Approaches to Education Research. Available online: http://www.edu.plymouth.ac.uk/resined/narrative/narrativehome.htm (accessed on 13 May 2013).

49. Levidow, L.; Birch, K.; Papaioannou, T. Divergent paradigms of European agro-food innovation: The knowledge-based bio-economy as an R\&D agenda. Sci. Techn. Hum. Val. 2012, 38, 94-125. 
50. Levidow, L.; Birch, K.; Papaioannou, T. EU agri-innovation policy: Two contending visions of the bio-economy. Crit. Policy. Stud. 2012, 6, 40-65.

51. Luoma, P.; Vanhanen, J.; Tommila, P. Distributed Bio-Based Economy: Driving Sustainable Growth; SITRA: Helsinki, Finland, 2011.

52. Latham, J.; Wilson, A. Does the bio-economy add up? Available online: http://independents ciencenews.org/ (accessed on 12 May 2013).

53. Smolker, R. The new bioeconomy and the future of agriculture. Development 2008, 51, 519-526.

54. Jordan, N.; Boody, G.; Broussard, W.; Glover, J.D.; Keeney, D.; McCown, B.H.; McIsaac, G.; Muller, M.; Murray, H.; Neal, J.; et al. Sustainable development of the agricultural bio-economy. Science 2007, 316, 1570-1571.

55. European Bioplastics. National bioeconomy strategy launched in USA. Available online: http://en.european-bioplastics.org/blog/2012/05/18/us-launches-national-bioeconomy-strategy/ (accessed on 13 May 2013).

56. International Risk Governance Council (IRGC). Risk Governance Guidelines for Bioenergy Policies; International Risk Governance Council: Geneva, Switzerland, 2008.

57. German Advisory Council on Global Change (WBGU). World in Transition: Future Bioenergy and Sustainable Land Use; Earthscan: London, UK, 2009.

58. Kampman, B.; Bergsma, G.; Schepers, B.; Croezen, H.; Fritsche, U.R.; Henneberg, K.; Huenecke, K.; Molenaar, J.W.; Kessler, J.J.; Slingerland, S.; et al. BUBE: Better Use of Biomass for Energy; CE Delft, Öko-Institut: Delft, The Netherlands, 2010.

59. United Nations Environment Programme (UNEP). Beyond the Talk: Engaging Stakeholders in Bioenergy Development; United Nations Environment Programme: Paris, France, 2010.

60. Bauen, A.; Berndes, G.; Junginger, M.; Londo, M.; Vuille, F.; Ball, R.; Bole, T.; Chudziak, C.; Faaij, A.; Mozaffarian, H. Bioenergy: A Sustainable and Reliable Energy Source. Available online: http://www.ieabioenergy.com/libitem.aspx?id=6479 (accessed on 13 May 2013).

61. European Commission (EC). Report from the Commission: Sustainability requirements for the use of solid and gaseous biomass sources in electricity, heating and cooling; COM (2010) final; European Commission: Brussels, Belgium, 2010.

62. Börjesson, P.; Ericsson, K.; di Lucia, L.; Nilsson, L.J.; Åhman, M. Sustainable Vehicle Fuels: Do They Exist? Lund University: Lund, Sweden, 2009.

63. Rosenthal, E. Scientists take a second look at biofuels. New York Times, 31 January 2007. Available online: http://www.nytimes.com/2007/01/30/business/worldbusiness/30iht-biofuel. 4411627.html?pagewanted=all (accessed on 13 may 2013).

64. Renewable Fuels Agency (RFA). The Gallagher Review of the Indirect Effects of Biofuels Production; Renewable Fuels Agency: East Sussex, UK, 2008.

65. Solomon, B.D. Biofuels and sustainability. Ann. NY Acad. Sci. 2010, 1185, 119-134.

66. World Wide Fund for Nature (WWF). Position Paper on Bioenergy. Available online: http://awsassets.panda.org/downloads/final_bioenergy_policy_external_april_2012.pdf (accessed on 13 May 2013).

67. European Commission (EC). Communication from the Commission: Europe's climate change opportunity; COM (2008)30; European Commission: Brussels, Belgium, 2008. 
68. Edwards, R.; Szekeres, S.; Neuwahl, F.; Mahieu, V. Biofuels in the European Context: Facts and Uncertainties. Available online: http://ec.europa.eu/dgs/jrc/downloads/jrc_biofuels_report.pdf (accessed on 13 May).

69. Birdlife International; European Environmental Bureau (EEB); Transport and Environment (T\&E). Bioenergy: A Carbon Accounting Time Bomb. Available online: http://www.birdlife.org/ eu/pdfs/carbon_bomb_21_06_2010.pdf(accessed on 13 Mat 2013).

70. Croezen, H.; Bergsma, G.; Otten, M.; van Valkengoed, M. Biofuels: Indirect Land Use Change and Climate Impact; CE Delft: Delft, The Netherlands, 2010.

71. European Association for Bioindustries (EuropaBio). Biofuels in Europe: EuropaBio position and specific recommendations. Available online: http://www.europabio.org/sites/default/files/ position/biofuels_in_europe.pdf(accessed on 12 May 2013).

72. Mathews, J.A. From the petroeconomy to the bioeconomy: Integrating bioenergy production with agricultural demands. Biofuel. Bioprod. Bior. 2009, 3, 613-632.

73. European Commission (EC). Commission sets up system for certifying sustainable biofuels; Available online: http://europa.eu/rapid/press-release_IP-10-711_en.htm (accessed on 13 May 2013).

74. Ten Pierick, E.; van Mil, E.M.; Meeusen, M.J.G. Transition Towards a Biobased Economy. In The Biobased Economy: Biofuels, Materials and Chemicals in the Post-oil Era; Langeveld, J.W., Sanders, J.P.M., Meeusen, M., Eds.; Earthscan: London, UK, 2010; pp. 18-32.

75. Staffas, L.; Gustavsson, M.; McCormick, K. Strategies and Policies for the Bioeconomy and Bio-based Economy: An analysis of official national approaches. Sustainability 2013, accepted.

(C) 2013 by the authors; licensee MDPI, Basel, Switzerland. This article is an open access article distributed under the terms and conditions of the Creative Commons Attribution license (http://creativecommons.org/licenses/by/3.0/). 